\title{
Model Investigasi Kelompok Siber Sebagai Alternatif Pembelajaran Menulis Teks Eksposisi
}

\author{
Ayu Lestari \\ E-mail: ayulestariduri10@gmail.com \\ Program Studi Pendidikan Bahasa dan Sastra Indonesia, Universitas Riau
}

\section{Pengantar}

Kegiatan belajar mengajar tidak akan lepas dari sesuatu yang berbasis pada teks. Di sekolah menengah, pembelajaran berbasis teks sudah menjadi hal yang umum dalam bidang pendidikan. Telah terbagi atas beberapa jenis, salah satunya yakni teks eksposisi yang umumnya diajarkan pada siswa kelas X. Peserta didik di tuntut untuk mempelajari beberapa bagian pada teks eksposisi, agar tercapainya tujuan pembelajaran dan berpengaruh terhadap perkembangan sikap peserta didik. Guru harus lebih memperhatikan dalam pembelajaran teka eksposisi, keterampilan peserta didik juga harus diperhatikan tidak hanya sekedar memahami materi saja. Selain itu, model pembelajaran menjadi bagian penting dalam kegiatan belajar mengajar. Guru dituntut untuk dapat menerapkan model pembelajaran yang sesuai dan relevan dengan materi yang akan diajarkan. (Andrystiawan, 2016) menyatakan tujuan diterapkannya suatu model dalam pembelajaran adalah untuk mempermudah siswa dalam mencapai tujuan belajar.

Saat ini masih banyak ditemui guru yang hanya mendominasi saat proses pembelajaran di kelas khususnya pada pembelajaran Bahasa Indonesia pada materi teks eksposisi. Kebanyakan guru hanya menggunakan metode ceramah atau hanya menggunakan buku sebagai pendukung dalam proses pembelajaran. Di zaman yang semakin canggih, guru harus lebih selektif dalam melaksanakan pembelajaran dengan menggunakan model pembelajaran yang kreatif dan sesuai dengan karakteristik materi yang diajarkan. (Zulhafizh, Atmazaki, Syahrul R, 2013) mengungkapkan bahwa proses belajar yang baik dapat menghasilkan kegiatan pembelajaran yang dapat mencapai hasil yang baik.

(M. Nur Mustafa, Hermandra, Zulhafizh, 2019) menyatakan bahwa seorang guru dituntut untuk membantu peserta didik agar dapat memahami pembelajaran secara teoritis dan praktis. Pada model investigasi kelompok siber ini tugas guru hanya mengawasi pembelajaran serta menyediakan pilihan pada peserta didik. Sejalan dengan konsep pembelajaran abad 21 yang diungkapkan oleh Zulhiyah (2013), bahwa untuk mencapai tujuan kompetensi yang dilakukan 
secara tim atau kelompok dapat dilakukan dengan menerapkan karakter 4C diantaranya kreativitas (creativity), berpikir kritis (critical thinking), kolaborasi (collaborative) dan komunikasi (communication). Dengan adanya penerapan keempat konsep tersebut, dapat melatih peserta didik lebih berpengaruh dibandingkan dengan peran guru saat kegiatan belajar mengajar di kelas.

Model pembelajaran investigasi kelompok siber daring untuk pembelajaran menulis teks eksposisi disesuaikan oleh kondisi zaman dan peserta didik yang semakin milenial, sehingga model ini cocok dikembangkan untuk menunjang keberhasilan dalam pembelajaran. Pemanfaatan teknologi serta jaringan dapat membantu peserta didik dalam mencari data-data yang dibutuhkan. Keuntungan dalam penggunaan model pembelajaran daring pada materi menulis teks eksposisi yaitu peserta didik menjadi lebih kreatif dan inovatif. Dengan diterapkannya model investigasi kelompok siber ini diharapkan peserta didik dapat lebih aktif dan kreatif dalam mengembangkan kreativitasnya dalam menulis teks eksposisi dengan cara dan inovasinya sendiri, dan lebih mudah untuk mengembangkan ide yang akan dijadikan sebagai bahan menulis teks eksposisi.

\section{Hakikat Model Pembelajaran Investigasi Kelompok Siber}

Model investigasi kelompok siber dirancang untuk memanfaatkan kemajuan teknologi yang semakin canggih. Model ini berbasis pada teknologi dan jaringan internet. Dalam model investigasi kelompok peserta didik hanya akan mengamati secara langsung sebuah objek, sedangkan pada model investigasi kelompok siber peserta didik akan memanfaatkan kecanggihan teknologi dengan cara melakukan pencarian data yang tidak didapatkan di buku yakni melalui internet. Dengan menggunakan internet peserta didik dapat mencari data-data yang akan digunakan untuk bahan menulis teks eksposisi.

Model investigasi kelompok siber akan membantu mengembangkan kreativitas peserta didik. Model ini bukan sekedar untuk memperlancar siswa dalam pencarian data-data yang akan digunakan untuk bahan menulis, melainkan juga dapat membantu peserta didik untuk menimbulkan kesadaran dalam dirinya bahwa teknologi, internet, dan media sosial bukan hanya digunakan untuk hal-hal yang tidak bermanfaat, melainkan juga dapat dimanfaatkan untuk belajar. 


\section{Sarana Pendukung}

Sarana pendukung dalam melaksanakan model Investigasi Kelompok Siber ini bergantung pada sistem hubungan yang digunakan. Sarana yang digunakan dalam sistem daring merupakan seperangkat teknologi yang dapat terhubung dengan jaringan dan internet. Berikut merupakan sarana pendukung dalam pelaksanaan Model Investigasi Kelompok Siber sebagai alternatif pembelajaran menulis teks eksposisi.

\section{a. Komputer}

Komputer merupakan sarana pendukung utama dalam melaksanakan model investigasi kelompok siber ini. Melalui komputer akan membantu peserta didik dalam mencari datadata yang tidak ditemukan di buku mengenai materi atau bahan yang akan digunakan dalam penulisan teks eksposisi.

\section{b. Wifi}

Selain komputer atau ponsel, pendukung utama dalam melaksanakan model investigasi kelompok siber juga membutuhkan jaringan internet seperti wifi. Maka pihak sekolah harus menyediakan sarana jaringan internet seperti wifi. Melalui wifi akan membantu peserta didik untuk mengoperasikan komputer atau ponsel yang akan digunakan untuk mencari data-data sebagai bahan penulisan teks eksposisi.

\section{c. Power Point}

Melalui power point akan membantu peserta didik agar lebih mudah memahami materi teks eksposisi. Power point juga merupakan salah satu media yang paling sering digunakan oleh guru untuk menjelaskan suatu materi.

\section{d. Form Penilaian}

Kegiatan belajar mengajar tidak luput dari form penilaian, karena dengan menggunakan form penilaian seorang pendidik dapat mengetahui dan menghitung sejauh mana pemahaman serta ketercapaian peserta didiknya pada materi pembelajaran teks eksposisi.

\section{Tindakan Solutif}

Dalam pelaksanaan pembelajaran teka eksposisi dengan menggunakan Model Investigasi Kelompok Siber Daring tentunya terdapat kemungkinan munculnya berbagai hambatan atau masalah dalam proses pelaksanaannya. Kemungkinan kendala yang akan muncul beserta solusinya yakni sebagai berikut: 
1. Masih terbatasnya sekolah yang memiliki fasilitas seperti komputer atau laptop yang akan digunakan peserta didik untuk mencari data-data, sehingga pelaksanaan model investigasi kelompok siber daring mungkin akan sulit diterapkan.

Solusi: Guru dapat mengarahkan peserta didik yang memiliki laptop atau ponsel pribadi untuk dapat dibawa pada saat pembelajaran teks eksposisi dengan model investigasi kelompok siber daring.

2. Di sekolah tidak disediakan wifi.

Solusi: Guru dapat memberikan hotspot kepada peserta didik saat pelaksanaan pembelajaran teks eksposisi dengan model investigasi kelompok siber daring. Atau bisa juga dengan menggunakan kuota pribadi masing-masing peserta didik.

3. Tidak disediakannya power point mengenai materi teks eksposisi oleh guru.

Solusi: Guru dapat meminjamkan buku kepada peserta didik untuk mencari serta memahami materi tentang teks eksposisi.

4. Masih banyaknya guru yang belum memahami cara pengoperasian form penilaian.

Solusi: Guru dapat mengikuti pelatihan dan seminar mengenai bagaimana cara pengoperasian form penilaian secara daring.

\section{Langkah-langkah Implementasi Pembelajaran Teks Eksposisi Dengan Model Investigasi}

\section{Kelompok Siber Daring}

Implementasi pembelajaran teks eksposisi dengan menggunakan model investigasi kelompok siber daring dapat dilaksanakan dengan cara sebagai berikut:

1. Guru membentuk kelompok belajar yang terdiri atas 5-6 peserta didik. Selanjutnya kelompok belajar menggali permasalahan yang akan dijadikan teman pembahasan dalam kelompok.

2. Peserta didik melakukan diskusi dengan tujuan agar dapat menentukan satu topik yang dipilih untuk dibahas bersama anggota kelompok. Guru harus terlibat dalam proses ini agar dapat mengarahkan peserta didik untuk mengembangkan topik yang dipilih menjadi sebuah teks eksposisi. 
3. Selanjutnya, peserta didik akan mencari data-data bersama dengan kelompoknya. Data yang dimaksud adalah seperti artikel atau sumber-sumber lain yang di dalamnya membahas mengenai topik yang telah disepakati anggota kelompok. Pencarian data ini dilakukan dengan memanfaatkan teknologi yakni komputer atau ponsel serta didukung dengan jaringan internet seperti wifi atau hotspot yang disediakan oleh sekolah.

4. Tahap selanjutnya yaitu, peserta didik melakukan pembagian tugas dalam menganalisis data dan memisahkan data yang valid dan menarik. Jika data berupa artikel yang terdiri atas beberapa paragraf, maka pembagiannya sesuai porsi dan jumlah anggota kelompok agar tidak memakan waktu yang terlalu lama. Serta melatih setiap anggota kelompok untuk aktif dalam pembelajaran.

5. Selanjutnya tahap kegiatan belajar, pada tahap ini peserta didik akan mulai mengerjakan tugas-tugas yang sudah dibagi. Data yang sudah di dapatkan akan dianalisis. Hal-hal yang dapat diambil dari data dapat berupa fakta-fakta, pendapat, dan lain sebagainya.

6. Setelah itu kelompok akan menyatukan data yang sudah dianalisis menjadi satu kesatuan. Lalu selanjutnya kelompok mulai mengembangkan baik fakta maupun hal-hal menarik yang telah di dapat menjadi sebuah teks eksposisi. Setiap kelompok akan mendapatkan hasil yang berbeda, karena setiap individu pasti memiliki kreativitas tersendiri.

7. Setelah teks eksposisi selesai ditulis oleh masing-masing kelompok, selanjutnya guru akan melakukan pembahasan pada masing-masing teks eksposisi setiap kelompok. Tujuannya untuk memberikan gambaran mengenai teks eksposisi yang benar dan bagus.

8. Setelah teks eksposisi dikoreksi oleh guru maka peserta didik diminta untuk mempublikasikan karyanya di sosial media yang dimiliki oleh peserta didik. Tujuannya untuk melihat respon pembaca dan melihat masukan dari pembaca mengenai karya peserta didik.

9. Pada tahap terakhir menggunakan model investigasi kelompok siber daring guru mengajak peserta didik untuk melakukan diskusi yang berkenaan dengan pembelajaran menulis teks eksposisi yang telah dilaksanakan. Kegiatan diskusi ini membahas tentang kesulitan yang dialami, serta hal-hal yang dirasakan peserta didik selama pembelajaran. Selain itu peserta didik juga dapat memberikan kritik dan saran kepada guru mengenai hal-hal yang berkaitan dengan proses pembelajaran yang telah dilakukan. 


\section{Simpulan}

Teks eksposisi merupakan suatu bentuk tulisan atau retorika untuk menerangkan dan menguraikan suatu pokok pikiran yang dapat memperluas pandangan atau pengetahuan pembaca (Tahir, 2017). Teks eksposisi mengandalkan strategi pembangunan alinea seperti pemberian contoh, proses, sebab akibat, klasifikasi, definisi, analisis, komparasi, dan kontras. Penulisan teks eksposisi sangat memberikan manfaat lebih terutama kepada pembaca dalam mengetahui informasi, keadaan, ataupun isu yang tengah terjadi.

Pembelajaran menulis teks eksposisi menggunakan model investigasi kelompok siber daring diterapkan pada peserta didikdi sekolah menengah atas. Hal ini disebabkan karena model investigasi kelompok siber daring ini memanfaatkan jaringan internet yang jumlah informasinya tidak terbatas. Model ini juga mengajarkan peserta didik untuk memberikan pengalaman dan pemahaman secara kelompok maupun mandiri. Sehingga dapat tercapainya tujuan pembelajaran pada materi menulis teks eksposisi.

\section{Referensi}

Adri, Muhammad. 2007. Pemanfaatan Internet sebagai Sumber Pembelajaran. Komunitas elearning Ilmu Komputer.Com

(http://muhammadadri.wordpress.com) (diakses pada 7 Januari 2020)

Motivasi, sikap, dan hasil belajar http://103.216.87.80/index.php/bsp/article/viewFile/4991/3943

Zulhafizh, Atmazaki, \& Syahrul, R. (2013). Kontribusi Sikap dan Motivasi Belajar Siswa terhadap Hasil Belajar Bahasa Indonesia. Jurnal Bahasa, Sastra dan Pembelajaran, 1(2), $13-28$.

Media pembelajaran https://jes.ejournal.unri.ac.id/index.php/JES/article/download/6972/6177 Mustafa, M. N., Hermandra, \& Zulhafizh. (2019). Teachers' Strategies to Design Media to Implement Communicative Leaning in Public Schools. Journal of Educational Sciences, 3(1), 13-24.

Agustyani. 2016. Keefektifan Pembelajaran Menulis Teks Berita Menggunakan Model Peta Konsep dan Model Investigasi Kelompok pada Siswa Kelas VIII. Skripsi: Universitas Negeri Semarang.

Anggraini, Lela. 2010. Penerapan Model Pembelajaran Investigasi Kelompok untuk Meningkatkan Kemampuan Pemecahan Masalah Matematika Siswa Kelas VIII-4 SMP Negeri 27 Palembang. Artikel. Palembang: Unsri. 
Ayuni, Eka dan Pristiwati, Rahayu. 2019. Keefektifan Pembelajaran Mengonstruksi Teks Eksposisi secara Tulis Menggunakan Model Investigasi Kelompok (IK) dan Model Cooperative Integrated Reading and Composition (CIRC) berbantuan Media Tayangan Mata Najwa pada Peserta Didik kelas X SMA. Skripsi : Universitas Negeri Semarang. 


\section{*Data Penulis}

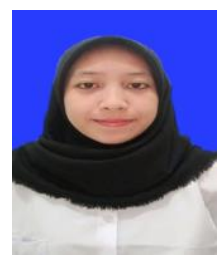

Ayu Lestari, lahir di Duri, 10 November 2001. Pada tahun akademik 2020-2021, Ia melanjutkan studi pada strata satu Jurusan Pendidikan Bahasa dan Seni di Program Studi Pendidikan Bahasa dan Sastra Indonesia FKIP Universitas Riau melalui jalur SBMPTN (Seleksi Bersama Masuk Perguruan Tinggi Negeri). Prestasi yang pernah diraih adalah menjadi peserta pada kegiatan Bulan Bahasa dan Praktikum Sastra dalam "Lomba Menulis Puisi dan Menulis Esai” yang diselenggarakan oleh FKIP Universitas Riau.

Kontak : 085263418150

Hp/WA : 085274568300

Email : ayulestariduri10@gmail.com 